of Columbia and Canada. Illinois leads all the other states with fifty-six members, Missouri comes second with twenty-six, Iowa and Nebraska ' tie with twenty-five each, while Ohio has nineteen, Wisconsin fifteen, Michigan eleven, Wyoming ten, etc. These members represent seventy-one colleges, universities and normal schools, sixty-seven public and state libraries, and forty-four historical societies.

\title{
REMOVAL OF GOVERNOR BRIGGS' BODY TO IOWA.
}

One of the most commendable things accomplished by the Thirty-third General Assembly was the carrying out of the plan of Hon. J. W. Ellis, the Representative from Jackson county, of returning to Iowa soil the body of Ansel Briggs, the first governor of Iowa. Jackson county was the home of Governor Briggs when he was elected in 1846 and during his incumbency of the office for two terms. He resided at the old town of Andrew until 1870, except for a few years spent in Colorado. In 1870 he removed to Council Bluffs, where his home remained until his death, May 5, 1881. He died at the residence of his son, J. S. Briggs, in Omaha, Nebraska, and his body was interred at that place. For a number of years the return of Gov. Briggs' body to Iowa and to his former home was urged by prominent citizens, but the eredit of accomplishing this good work is almost wholly due to Mr. Ellis, whose election to the House and whose labors there had this as the central purpose. An appropriation of $\$ 1,000$ was made by the State from which to defray the expense and provide a suitable monument to be erected over the grave. The monument, as designed, is to be of granite, in the form of a monolith twelve feet high, on a base bearing a bronze medallion portrait of Governor Briggs, appropriate inscriptions commemorating his life and services, and an outline map of the State of Iowa. 
Copyright of Annals of Iowa is the property of State of Iowa, by \& through the State Historical Society of Iowa and its content may not be copied or emailed to multiple sites or posted to a listserv without the copyright holder's express written permission. However, users may print, download, or email articles for individual use. 